\title{
Breed and season influence on milk quality parameters and in mastitis occurrence ${ }^{1}$
}

\author{
Diego B. Nóbrega ${ }^{2}$ and Hélio Langoni ${ }^{2 *}$
}

\begin{abstract}
Nóbrega D.B. \& Langoni H. 2011. Breed and season influence on milk quality parameters and in mastitis occurrence. Pesquisa Veterinária Brasileira 31(12):1045-1052. Departamento de Higiene Veterinária e Saúde Pública, Faculdade de Medicina Veterinária e Zootecnia, Universidade Estadual Paulista, Distrito de Rubião Júnior s/n, Botucatu, SP 18618900, Brazil. E-mail: higivet@fmvz.unesp.br

The aims of the present study were to evaluate the performance of Jersey and Holstein cows under different rainfall conditions (dry and rainy seasons) by monitoring aspects related to subclinical mastitis (somatic cell count, microbiological isolation, type of isolated pathogen), milk quality (lactose, protein, fat, total solids) and production (mean milk production) of both breeds. The study was carried out in a dairy farm located in the state of São Paulo, Brazil. Eight visitations were done to the farm, four in a period of high rainfall and four in a period of low rainfall. Milk samples were collected from 79 Holstein cows and 37 Jersey cows for electronic somatic cell count and determination of the main milk components (protein, fat, total solids, lactose). Milk fat, protein, total solids and production were influenced by breed and the season, with similar tendencies for both breeds in both seasons. Somatic cell count (SCC) showed similar results for both breeds. Holstein cows with intramammary infections (IMI) presented a higher increase in SCC when compared to Jersey cows $(P<0.001)$. In the dry season, 53 animals had IMI in at least one month during the study, which 32 were Holstein and 21 were Jersey cows. In the rainy season, 65 animals had intramammary infection, being 43 Holstein and 22 Jersey cows. The frequency of IMI cases was larger in the rainy season than in the dry season. Jersey cows had a lower chance of showing IMI signs and symptoms than Holstein cows in the rainy season (odds ratio=0.52). The larger number of IMI cases in the rainy season may have led to a lower milk lactose rate for both breeds, thus milk lactose rate can be considered an indicator of IMI status. There was prevalence of contagious pathogens overall in the study. The applied model showed that environmental pathogens were more frequently isolated from the breed Jersey, regardless of the study season. There seems to be differences in the immune response of Jersey and Holstein breeds.
\end{abstract}

INDEX TERMS: Holstein, Jersey, mastitis, season.

RESUMO.- [Influência da raça e estação em aspectos de qualidade do leite e na ocorrência de mastites.] Os objetivos do presente estudo foram avaliar a performance das raças Jersey e Holandesa em diferentes condições de pluviosidade (estações seca e chuvosa) através do monitoramento de aspectos relacionados com a mastite subclínica (contagem de células somáticas, isolamento microbiológi-

\footnotetext{
${ }^{1}$ Received on April 9, 2011.

Accepted for publication on August 9, 2011.

${ }^{2}$ Departamento de Higiene Veterinária e Saúde Pública, Faculdade de Medicina Veterinária e Saúde Pública, Universidade Estadual Paulista (Unesp), Distrito de Rubião Júnior s/n, Botucatu, SP 18618-970, Brazil. *Corresponding author: hlangoni@fmvz.unesp.br
}

co, tipo de patógeno isolado), qualidade do leite (lactose, proteína, gordura e sólidos totais) e produção (media da produção de leite) de ambas as raças. 0 estudo foi conduzido em propriedade leiteira localizada no estado de São Paulo, Brasil. Oito visitas foram realizadas a propriedade, quatro em período de alta pluviosidade e outro em período de baixa pluviosidade. Amostras de leite foram colhidas de todos os animais para contagem eletrônica de células somáticas e determinação dos principais componentes do leite (proteína, gordura, sólidos totais, lactose). Gordura, proteína, sólidos totais e produção leiteira foram influenciadas tanto pela raça como pela estação, apresentando tendências similares para ambas raças em ambas estações. A con- 
tagem de células somáticas (CCS) apresentou resultados similares para ambas as raças. Vacas holandesas com infecção intramamária (IIM) apresentaram um maior aumento na CCS quando comparadas as vacas Jersey $(P<0.001)$. Na estação seca, 53 animais tiveram IIM em pelo menos um mês do estudo. Destes, 32 eram da raça Holandesa e 21 da raça Jersey. Na estação chuvosa, 65 animais possuíram infecção intramamária, dos quais 43 eram da raça Holandesa e 22 da raça Jersey. A frequência de casos de IIM foi maior na estação chuvosa em comparação à estação seca. Vacas Jersey apresentaram uma menor chance de desenvolver sinais e sintomas de IIM em relação às vacas holandesas na estação chuvosa (razão de chances $=0.52$ ). 0 maior numero de casos de IIM na estação chuvosa pode ter contribuído para uma menor taxa de lactose no leite para ambas as raças, sendo que esta pode ser considerada como um indicador do status de IIM. Existiu uma prevalência de patógenos contagiosos durante todo o experimento. 0 modelo estatístico aplicado mostrou que patógenos ambientais foram mais frequentemente isolados da raça Jersey, independentemente do período do estudo. Aparentemente existem diferenças na resposta imune das raças Jersey e Holandesa.

TERMOS DE INDEXAÇÃO: Holandesa, Jersey, mastite, estação.

\section{INTRODUCTION}

Mastitis is the most frequent and costly disease in dairy cattle and economic losses can be attributed to both clinical and subclinical forms of the disease. Subclinical mastitis occurs when a pathogen infects one or more quarters but does not cause enough disruption of the secretory alveoli to result in visible abnormal milk (Caraviello et al. 2005).

Increased somatic cell count (SCC) is one indicator of bacterial infection of mammary gland (Langoni 2000, Park et al. 2007). High SCC is associated with altered protein quality, fatty acid composition, lactose, ion and mineral concentration, besides higher enzymatic activity and $\mathrm{pH}$ of raw milk (Auldist et al. 1996).

It is known that climate can affect mastitis incidence (Morse et al. 1988). The reservoirs for environmental pathogens are water, manure and dirt present in the environment. When teats and udder become wet and dirty, bacteria can infect the udder (Schreiner \& Ruegg 2002). Dirty udders were found to be a significant risk factor for the presence of Klebsiella after the pre-milking routine (Munoz et al. 2008). Udder cleanliness is thought to influence the quantity and type of bacteria present on teat surfaces, and dirty teats and udders are considered to be a source of environmental bacteria in milk (Schreiner \& Ruegg 2003).

Successful selection for milk production has contributed to the prevalence of the Holstein breed around the world (Heins et al. 2008). Recent studies have compared the innate immune responses of Holstein and Jersey cows, indicating that differences may exist between these two breeds (Bannerman et al. 2008a).

The aims of the present study were to evaluate the performance of Jersey and Holstein cows under different rainfall conditions (dry and rainy seasons) by monitoring aspects related to subclinical mastitis (SCC, microbiological isolation, type of isolated pathogen), milk quality (lactose, protein, fat, total solids) and production (mean milk production) of both breeds.

\section{MATERIALS AND METHODS}

The study was carried out in a dairy farm located in the São Paulo state, Brazil, housing around 140 animals of different ages and lactation numbers, of which nearly 40 were Jersey cows and the remaining were Holstein cows, all kept under the same conditions. The animals were submitted to the same diet, based mainly on pasture (grass pasture system) and corn silage. The animals were supplemented with concentrate in both seasons, with a higher intake during the dry season. Eight monthly visitations were done to the farm, four in a high rainfall period and four in a low rainfall period. Only animals that were present in, at least, three months in each period participated in the study, totaling 79 Holstein and 37 Jersey cows. Daily rainfall index values were obtained from the farm, where internal control was done using its own pluviometer (rain gauge). These values were added in order to obtain a monthly value. The four months in a row with higher values were grouped as the rainy station. The others were grouped as the dry station.

In each month, animals were subjected to the California Mastitis Test (CMT) (Schalm \& Noorlander 1957). Teats with milk samples presenting reaction from score three (1-5 grade) had milk samples collected in duplicate for microbiological analysis into sterile flasks after cleaning, washing with tap water, drying with disposable paper towel and teat ostium disinfection with alcoholic iodine solution 5\%. Milk samples were collected from all animals for electronic somatic cell count (eSCC) and determination of the main milk components (protein, fat, total solids, lactose). Analyses were done in a Bentley 2500 Combi (Bentley) unit in an accredited laboratory. Milk samples were collected from each animal after homogenization, representing the whole milking process and not only one specific moment.

All collections were performed monthly at the same day period (in the morning, second milking) in order to minimize the effects of the natural variation in milk composition over the day on the analysis of results. Monthly spreadsheets containing production data (lactation number, days in milk, mean monthly production) were obtained.

\section{Microbiological analysis}

Microbiological culture was done according to standard procedures of the National Mastitis Council (NMC 1999). Staphylococci were subjected to coagulase test. Coagulase-positive staphylococci were considered to be Staphylococcus aureus, while coagulase-negative staphylococci (CNS) were grouped as Staphylococcus spp. Gram-positive, catalase-negative cocci were identified as members of the Streptococcaceae family and were subjected to CAMP and esculin hydrolysis tests. Gram-positive, pleomorphic and catalase-positive coccobacilli were classified within the Corynebacterium genus. Samples presenting more than three types of microbial pathogens were considered contaminated. Major mastitis pathogens included isolation of Staphylococcus aureus, Streptococcus spp., Arcanobacterium pyogenes or coliform species, while minor mastitis pathogens were defined as CNS or Corynebacterium species. Pathogens were also classified according to their origin into contagious and environmental.

Intramammary infection (IMI) was defined at teat level as the positive result to both CMT and the microbiological isolation, associated with the pathogen type (major or minor), requiring at 
least three colonies of minor pathogens per mL milk and one or more colonies of major pathogens. If one of the duplicate samples was contaminated, the results from the uncontaminated duplicate were used to diagnose the infection. When a quarter had both major and minor pathogens isolated simultaneously, the quarter was defined as infected by the major pathogen. Milk samples contaminated or not collected were defined as missing values for analysis. IMI was considered positive at animal level based on the positive isolation in, at least, one mammary quarter. If different pathogens were responsible for IMI signs and symptoms at teat level in the same animal, all major pathogens involved were considered responsible for IMI at animal level. To determine the pathogen responsible for IMI in one season, all major pathogens isolated at animal level in all months were considered responsible for the IMI in the specific season.

\section{Statistical analysis}

All analyses were performed at animal level. Univariate analysis was done to determine measures of central tendency, dispersion and distribution characteristics of all variables studied in the experiment. Separate histograms were created to evaluate the distributions of the studied variables for both breeds. Two types of analysis were done:

\section{Analysis of months}

Milk eSCC was log-transformed. T-tests were used for all quantitative variables (eSCC, lactose, fat, protein, total solids and monthly milk production) in order to detect differences between breeds in the several months. Levene's test was used to verify the homogeneity of variances and Kolmogorov-Smirnov test was adopted to evaluate the normality of variables separated according to breed and month. Chi-square test was employed with the same purpose of t-test but for qualitative variables (presence/ absence of IMI).

\section{Analysis of seasons}

The main objective of the study was the influence of the season, not the influence of the month on the milk quality parameters. So, for each animal, mean values of eSCC (log values), lactose, fat, protein, total solids and monthly milk production were calculated considering the two evaluated seasons. The eight months were grouped into two distinct seasons according to rainfall in order to compare distinct seasons. Repeated measures mixed models were performed to compare mean responses of variables in the two seasons and breed-dependent differences. Season, breed and their interaction were considered fixed effects. The interaction between presence/absence of IMI and breed was included in the initial model, in order to verify if the infection status could affect the milk parameters in different ways according to the breed. The three-way interaction (breed, season and infection status) was not included due to the relatively low cases number to detect significant effects. Lactation number was included as random effect. Correlations among repeated measures over time within and between breeds were modeled using appropriate covariance structures for each parameter analyzed. Estimated marginal means were calculated according to the model parameters. Least Significant Difference (LSD) methods with upper on lower bounds of $95 \%$ confidence interval (UB-95\%; LB-95\%) were used for adjustment of multiple comparisons of significant effects.

The logistic regression model was applied in order to evaluate the effect of changes in breeds and seasons on the IMI period status (presence or absence in the specific season). All 116 animals were evaluated, and contributed only once to the model.
Odds ratio was estimated at $95 \%$ confidence interval (CI). The initial model applied was:

$$
\operatorname{Logit}\left(\pi_{k l m n}\right)=\beta+\text { Lact }_{k}+\text { Season }_{l}+\text { Breed }_{m}+\text { Season }^{*} \text { Breed }+\varepsilon_{n}
$$

where $\pi$ is the probability of IMI existence ( $0=$ no, $1=y e s), \beta$ is the constant, Lact $_{k}$ is the lactation number (1 to 5 ), Season is $_{l}$ the season of the experiment (1=Dry, 2=Rainy), Breed ${ }_{m}$ is the animal breed (1=Holstein, 2=Jersey), Season*Breed is the interaction between season and animal breed and $\varepsilon_{\mathrm{n}}$ is the residual. Odds ratio (OR) was estimated at $95 \%$ confidence interval (CI). Goodness of fit for the logistic regression model was assessed using the Hosmer-Lemeshow test and graphical analysis of residuals and predicted values, respectively (Field \& Miles 2010). The predictors entered in the model in a backward conditional method. The final model contained the lactation number and the interaction as predictors. No collinearity was observed between variables using the correlation matrix.

Log-linear analysis was also adopted to verify possible effects of interaction between pathogen type (contagious/environmental), breed (Jersey/Holstein) and season (rainy/dry). These three variables were employed as factors and were inserted in a single step. Mixed infections (contagious/environmental) were not included in the model due to the low frequency of cases. Chisquare significance values (likelihood ratio and Pearson's tests) were obtained for all possible interactions and single effects (one, two and three way). Interactions were considered significant when their removal led to significant changes in the model and significant partial associations. Parameter estimates (95\% confidence interval) were calculated for each effect. The likelihood ratio test was used to verify whether the expected values generated by the model were not significantly different from the obtained data (Field \& Miles 2010). Significance level was set at 0.05 for all analyses.

\section{RESULTS}

The daily values of rainfall obtained with the rain gauge located in the farm were added according to the month. The first four months had $86,0,75$ and $49 \mathrm{~mm}^{3}$ rainfall and were grouped as dry season. In the last four months, rainfall was 119, 114, 282 and $398 \mathrm{~mm}^{3}$ respectively, and they were classified as rainy season.

In all months, breeds showed significant differences according to milk production, fat, protein and total solid rates. Values of milk lactose rate were significantly different only in month 8 due to the low values observed for the Jersey breed. In months 2 and 3, milk cellularity was higher in Jersey cows, which was not detected in the remaining months studied. The results for each studied month are shown in Table 1.

Regarding the presence/absence of IMI, breeds did not differ in any month $(P>0.05)$. When months were grouped into seasons, the following results were observed.

\section{Fat}

In the dry season, Holstein and Jersey cows had estimated marginal means of $3.03 \%$ and $4.11 \%$ fat in the milk, respectively. In the rainy season, these values increased to $3.25 \%$ and $4.50 \%$, respectively.

The study season had a significant effect on fat percentage in the milk, $F(1,219.49)=27.66, P<0.001$. There was 
Table 1. Mean values of milk production (liters), rates of fat, protein, lactose and total solids (Sol) in the milk (\%), and somatic cell count (SCC; cells/ml milk) according to the breed and the month

\begin{tabular}{ccccccccc}
\hline Season & Month & Breed & Production & Fat & Protein & Lactose & Sol & SCC \\
\hline Dry & 1 & Holstein & $36.75^{\mathrm{a}}$ & $2.83^{\mathrm{a}}$ & $2.85^{\mathrm{a}}$ & 4.57 & $11.13^{\mathrm{a}}$ & 171.83 \\
& 1 & Jersey & $23.32^{\mathrm{b}}$ & $4.10^{\mathrm{b}}$ & $3.45^{\mathrm{b}}$ & 4.59 & $13.12^{\mathrm{b}}$ & 206.30 \\
& 2 & Holstein & $34.76^{\mathrm{a}}$ & $2.90^{\mathrm{a}}$ & $2.87^{\mathrm{a}}$ & 4.44 & $11.11^{\mathrm{a}}$ & $154.66^{\mathrm{a}}$ \\
& 2 & Jersey & $24.45^{\mathrm{b}}$ & $4.01^{\mathrm{b}}$ & $3.38^{\mathrm{b}}$ & 4.54 & $12.93^{\mathrm{b}}$ & $285.69^{\mathrm{b}}$ \\
& 3 & Holstein & $34.01^{\mathrm{a}}$ & $2.85^{\mathrm{a}}$ & $2.95^{\mathrm{a}}$ & 4.45 & $11.15^{\mathrm{a}}$ & $154.56^{\mathrm{a}}$ \\
& 3 & Jersey & $23.60^{\mathrm{b}}$ & $4.84^{\mathrm{b}}$ & $3.61^{\mathrm{b}}$ & 4.59 & $14.13^{\mathrm{b}}$ & $367.62^{\mathrm{b}}$ \\
& 4 & Holstein & $34.67^{\mathrm{a}}$ & $2.90^{\mathrm{a}}$ & $2.83^{\mathrm{a}}$ & 4.61 & $11.24^{\mathrm{a}}$ & 102.71 \\
Rainy & 4 & Jersey & $24.54^{\mathrm{b}}$ & $4.04^{\mathrm{b}}$ & $3.34^{\mathrm{b}}$ & 4.60 & $13.00^{\mathrm{b}}$ & 128.17 \\
& 5 & Holstein & $32.85^{\mathrm{a}}$ & $2.99^{\mathrm{a}}$ & $2.95^{\mathrm{a}}$ & 4.50 & $11.48^{\mathrm{a}}$ & 138.38 \\
& 5 & Jersey & $22.59^{\mathrm{b}}$ & $4.22^{\mathrm{b}}$ & $3.42^{\mathrm{b}}$ & 4.51 & $13.34^{\mathrm{b}}$ & 110.94 \\
& 6 & Holstein & $34.10^{\mathrm{a}}$ & $3.08^{\mathrm{a}}$ & $2.96^{\mathrm{a}}$ & 4.54 & $11.48^{\mathrm{a}}$ & 120.14 \\
& 6 & Jersey & $23.31^{\mathrm{b}}$ & $4.37^{\mathrm{b}}$ & $3.5^{\mathrm{b}}$ & 4.51 & $13.43^{\mathrm{b}}$ & 115.90 \\
& 7 & Holstein & $29.73^{\mathrm{a}}$ & $3.05^{\mathrm{a}}$ & $3.02^{\mathrm{a}}$ & 4.54 & $11.48^{\mathrm{a}}$ & 99.97 \\
& 7 & Jersey & $20.37^{\mathrm{b}}$ & $4.47^{\mathrm{b}}$ & $3.61^{\mathrm{b}}$ & 4.52 & $13.55^{\mathrm{b}}$ & 87.96 \\
& 7 & Holstein & $29.25^{\mathrm{a}}$ & $3.54^{\mathrm{a}}$ & $3.09^{\mathrm{a}}$ & $4.40^{\mathrm{a}}$ & $11.95^{\mathrm{a}}$ & 284.38 \\
& 8 & Jersey & $19.09^{\mathrm{b}}$ & $4.77^{\mathrm{b}}$ & $3.71^{\mathrm{b}}$ & $4.28^{\mathrm{b}}$ & $13.78^{\mathrm{b}}$ & 274.91 \\
\hline
\end{tabular}

$\mathrm{a}_{-} \mathrm{b}$ Mean values of production, fat, protein, lactose, total solids and SCC from the same month followed by different letters shows significant differences between Jersey and Holstein cows on the respective month according to the T-test $(\mathrm{P}<0.05)$

no interaction between season and breed, $F(1,219.48)=$ $1.95, P=0.164$. In addition, the breed had an effect on fat rate, $F(1,219.80)=401.99, P<0.001$. The milk fat rate was breed- and season-dependent, and showed similar tendencies for both breeds in the two seasons. The estimated difference between season was 0.303 (LB95\% $=0.18$; UB95\% $=$ $0.41)$. The estimated difference between breeds was 1.162 $(\mathrm{LB} 95 \%=1.04 ; \mathrm{UB} 95 \%=1.27)$.

The interaction between breed and IMI status didn't contribute to the model $(P>0.05)$.

\section{Protein}

In the dry season, Holstein and Jersey cows had estimated marginal means of $2.87 \%$ and $3.32 \%$ protein in the milk, respectively. In the rainy season, these values increased to $3.01 \%$ and $3.52 \%$, respectively.

The study season had a significant effect on protein percentage in the milk, $F(1,223.89)=21.40, P<0.001$. There was no interaction between season and breed, $F(1,223.82)$ $=0.69, P=0.40$. In addition, the breed had an effect on protein rate, $F(1,224.57)=173.56, P<0.001$. The milk protein rate was breed- and season-dependent, and showed similar tendencies for both breeds in the two seasons. The estimated difference between season was 0.168 (LB95\% $=0.96$; UB95\% $=0.23$ ). The estimated difference between breeds was $0.480(\mathrm{LB} 95 \%=0.40$; UB95\% $=0.55)$.

The interaction between breed and IMI status didn't contribute to the model $(P>0.05)$.

\section{Total solids}

In the dry season, Holstein and Jersey cows had estimated marginal means of $11.25 \%$ and $12.93 \%$ total solids in the milk, respectively. In the rainy season, these values increased to $11.59 \%$ and $13.42 \%$, respectively.

The study season had a significant effect on total solid percentage in the milk, $F(1,226)=17.29, P<0.001$. There was no interaction between season and breed, $F(1,226)$ $=0.63, P=0.427$. In addition, the breed had an effect on to- tal solid rate, $F(1,226)=307.54, P<0.001$. The milk total solids rate was breed- and season-dependent, and showed similar tendencies for both breeds in the two seasons. The estimated difference between season was 0.415 (LB95\% $=0.21$; UB95\% $=0.61$ ). The estimated difference between breeds was 1.760 (LB95\% = 1.56; UB95\% = 1.95).

The interaction between breed and IMI status didn't contribute to the model $(P>0.05)$.

\section{Milk production}

In the dry season, Holstein and Jersey cows had estimated marginal means of 36.49 and 26.50 liters milk production, respectively. In the rainy season, these values decreased to 33.56 and 23.07 liters, respectively.

The study season had a significant effect on milk production, $F(1,223.29)=11.21, P<0.001$. There was no interaction between season and breed, $F(1,223.28)=0.06$, $P=0.79$. In addition, the breed had an effect on milk production, $F(1,223.47)=114.42, P<0.001$. The milk production was breed- and season-dependent, and showed similar tendencies for both breeds in the two seasons. The estimated difference between season was 3.183 (LB95\% = 1.31; UB95\% $=5.05)$. The estimated difference between breeds was 10.237 (LB95\% $=8.35$; UB95\% $=12.12$ ).

The interaction between breed and IMI status didn't contribute to the model $(P>0.05)$.

\section{Somatic cells}

SCC values were log-transformed in all analyses. The mean values were expressed according to the traditional metric scale.

In the dry season, Holstein and Jersey cows had estimated marginal means of 282.48 and 260.01 cells $/ \mathrm{ml}$, respectively. In the rainy season, these values increased to 313.32 and 266.07 cells $/ \mathrm{mLl}$, respectively.

The study season had no significant effect on SCC, $F(1$, $222.85)=0.19, P=0.659$. There was no interaction between period and breed, $F(1,222.85)=0.07, P=0.781$. Further- 
more, the breed had no effect on SCC, $F(1,223.01)=0.69$, $P=0.404$. SCC was not breed- or season-dependent, and showed similar tendencies for both breeds in the two season.

The interaction between breed and IMI status showed significant contribution to the model $(P<0.001)$. Jersey cows with presence of IMI had estimated marginal means of 151.70 cells $/ \mathrm{ml}$ while Holstein cows in the same condition presented mean values of 163.30 cells $/ \mathrm{ml}$. These values increased to 457.08 and 542.00 cells $/ \mathrm{ml}$ in Jersey and Holstein cows respectively in the presence of IMI. Holstein cows had a higher increase in SCC when an IMI case was present in comparrison with Jersey cows.

\section{Lactosis}

In the dry season, Holstein and Jersey cows had estimated marginal means of $4.40 \%$ and $4.46 \%$ regarding lactosis rate in the milk, respectively. In the rainy season, these values decreased to $4.33 \%$ and $4.31 \%$, respectively.

The study season had a significant effect on lactosis percentage in the milk, $F(1,221.94)=15.22, P<0.001$. There was no effect of the interaction between season and breed, $F(1,221.94)=1.822, P=0.178$, and there were no significant differences between breeds as to percentage of lactose in the milk, $F(1,222.03)=0.237, P=0.627$. The milk lactosis rate was season-dependent, and showed similar tendencies for both breeds in the two seasons. The estimated difference between seasons was 0.108 (LB95\% $=0.53$; UB95\% $=0.162$ ).

The interaction between breed and IMI status didn't contribute to the model $(P>0.05)$.

\section{IMI}

In the dry season, 53 animals had IMI (45.7\% of 116) in at least one month during the study. Of these, 32 were Holstein $(40.5 \%$ of 79$)$ and 21 were Jersey cows $(56.8 \%$ of 37$)$.

In the rainy season, 65 animals had IMI $(56.0 \%$ of the total), of which 43 were Holstein cows (54.4\% of all Holstein cows) and 22 Jersey cows (59.5\% of all Jersey cows), indicating that both breeds had increased frequency of IMI cases. The breed Jersey presented, in both seasons, a larger number of animals with IMI than healthy ones, which was not observed for Holstein cows.

According to the logistic regression model applied, the lactation number and the interaction between breed and season contributed to the model, as shown in Table 2.

$\mathrm{R}^{2}$ values indicate that the model had a mild effect and the predictors contributed to the output variable (presence/absence of IMI).

Results regarding the isolated pathogens according to both breed and season are presented in Table 3 .

Regarding the pathogens type, Holstein cows in dry season showed 22 IMI caused by pathogens classified as contagious $(68.75 \%$ of the total IMI for that breed in that season), 8 caused by environmental bacteria $(25.00 \%)$ and two cases of mixed infections (6.25\%). In rainy season, 34 IMI of the same breed were caused by contagious pathogens $(79.07 \%), 5$ by environmental bacteria $(11.63 \%)$ and 4 mixed infections $(9.30 \%)$.
Table 2. Coefficients of the logistic regression model (B) considering the presence/absence of intramammary infection as the outcome and their respective standard errors (SE), p-value, odds ratio values (ExpB) with lower (LB 95\%) and upper (UB 95\%) limits at 95\% confidence interval of variables included in the model, $R^{2}$ values of Hosmer-Lemeshow, Cox-Snell and Nagelkerke, and $\chi^{2}$ value and degrees of freedom of the model

\begin{tabular}{ccccc}
\hline Included & $\mathrm{B}(\mathrm{SE})$ & $\mathrm{LB} 95 \%$ & $\operatorname{Exp}(\mathrm{B})$ & $\mathrm{UB} 95 \%$ \\
\hline Lactation number & $0.839^{*}(0.238)$ & 1.45 & 2.31 & 3.69 \\
Breed*Season & $-0.649^{* *}(0.293)$ & 0.29 & 0.52 & 0.93 \\
Constant & $-0.837^{*}(0.333)$ & & 0.43 &
\end{tabular}

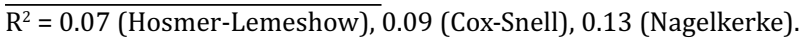
Model $\chi^{2}(2)=23.19$.

$* \mathrm{P}<0.05$.

$* * \mathrm{P}<0.001$.

Table 3. Absolute (N) and relative frequencies (\%) of isolated pathogens from milk samples of cows diagnosed with intramammary infection according to breed (Holstein and Jersey) and season (dry and rain)

\begin{tabular}{|c|c|c|c|c|}
\hline Breed & Season & Pathogen & $\mathrm{N}$ & $\%$ \\
\hline \multirow[t]{18}{*}{ Holstein } & \multirow[t]{8}{*}{ Dry } & Corynebacterium bovis & 5 & 15.6 \\
\hline & & Escherichia coli & 2 & 6.3 \\
\hline & & Staphylococcus aureus & 9 & 28.1 \\
\hline & & Staphylococcus spp. & 8 & 25.0 \\
\hline & & Streptococcus dysgalactiae & 6 & 18.8 \\
\hline & & Streptococcus dysgalactiae/Staphylococcus aureus & 1 & 3.1 \\
\hline & & Streptococcus uberis/Staphylococcus aureus & 1 & 3.1 \\
\hline & & Total & 32 & 100.0 \\
\hline & \multirow{10}{*}{ Rain } & Arcanobacterium pyogenes & 1 & 2.3 \\
\hline & & Corynebacterium bovis & 7 & 16.3 \\
\hline & & Escherichia coli & 1 & 2.3 \\
\hline & & Klebsiella pneumoniae/Staphylococcus spp. & 1 & 2.3 \\
\hline & & Staphylococcus aureus & 17 & 39.5 \\
\hline & & Staphylococcus spp. & 10 & 23.3 \\
\hline & & Streptococcus dysgalactiae & 3 & 7.0 \\
\hline & & Streptococcus dysgalactiae/Staphylococcus aureus & 2 & 4.7 \\
\hline & & Streptococcus dysgalactiae/Staphylococcus spp. & 1 & 2.3 \\
\hline & & Total & 43 & 100.0 \\
\hline \multirow[t]{17}{*}{ Jersey } & \multirow[t]{9}{*}{ Dry } & Corynebacterium bovis & 2 & 9.5 \\
\hline & & Pseudomonas aeruginosa & 2 & 9.5 \\
\hline & & Staphylococcus aureus & 5 & 23.8 \\
\hline & & Staphylococcus spp. & 3 & 14.3 \\
\hline & & Streptococcus dysgalactiae & 6 & 28.6 \\
\hline & & Streptococcus dysgalactiae/Staphylococcus aureus & 1 & 4.8 \\
\hline & & Streptococcus uberis & 1 & 4.8 \\
\hline & & Streptococcus uberis/Staphylococcus aureus & 1 & 4.8 \\
\hline & & Total & 21 & 100.0 \\
\hline & \multirow[t]{8}{*}{ Rain } & Corynebacterium bovis & 1 & 4.5 \\
\hline & & Escherichia coli & 2 & 9.1 \\
\hline & & Staphylococcus aureus & 5 & 22.7 \\
\hline & & Staphylococcus spp. & 7 & 31.8 \\
\hline & & Streptococcus dysgalactiae & 5 & 22.7 \\
\hline & & Streptococcus dysgalactiae/Staphylococcus aureus & 1 & 4.5 \\
\hline & & Streptococcus uberis/Staphylococcus aureus & 1 & 4.5 \\
\hline & & Total & 22 & 100.0 \\
\hline
\end{tabular}

Jersey cows showed 10 and 9 cases of IMI caused by contagious and environmental pathogens respectively (47.62\% and $42.86 \%)$ with $2(9.52 \%)$ mixed infections in dry season, and 13 (59.09\%) and 7 (31.82\%) IMI caused by contagious and environmental bacteria respectively with 2 (9.09\%) mixed infections in the rainy season.

The three-way log-linear analysis produced a final model containing two one-way effects (breed and pathogen type) and one two-way effect (breed $x$ pathogen type). The highest-order interaction (breed $\mathrm{x}$ season $\mathrm{x}$ pathogen type) was not significant, $\chi_{2}=0.185, P=0.667$. The two-way 
effect (breed x pathogen type) was significant $\left(\chi_{2}=5.82\right.$, $P=0.017$ ), showing that breeds differed according to the isolated pathogen type. No effect of season was found in the analyses. There seems to be no influence of season in the type of isolated pathogen for Holstein and Jersey cows.

It must be emphasized that animals chronically affected with IMI caused by a certain pathogen in a month of the study will probably present this pathogen again in the following month if not treated. However, for each animal, only one or more pathogens (in cases of mixed infections) were considered responsible for IMI, as described in the section "Materials and Methods".

\section{DISCUSSION}

Genetic differences among breeds of food-production animals are known to influence disease resistance, and several published studies have reported breed-dependent differences in the mastitis prevalence (Kelm et al. 2001). In the present work, we have observed different performances of both breeds regarding milk composition parameters when comparing the two seasons, probably due to distinct management procedures, and not necessarily due to genetic differences reflecting a better adaptation of one breed.

The variation in biochemical composition and technological properties of milk and dairy products has several origins: animal's diet, genetic factors and milk cold storage (Le Roux et al. 2003). Milk composition is also known to be highly dependent of the animal's health status, especially of the mammary gland health (Ogola et al. 2007). Milk fat and protein rates are modified by IMI (Seegers et al. 2003). It is also known that negative energy balance and protein imbalances decrease the animal immune defense. Disturbance in the metabolism may lead to the accumulation of fat in the liver, decreasing the functional capacity of the immune system, favoring the mastitis onset (Pyorala 2008). In the present study, the breeds were submitted to the same raising system (basically grass pasture), so any observed differences in the comparisons between breeds should be attributed to other factors. Comparisons of the same breed between the seasons may prove to be unrealistic, due to nutritional factors (higher concentrate intake during dry season).

Fat, protein and total solids rates in the milk increased in the rainy season for both breeds. Milk protein rate tends to increase in cases of IMI. Nielsen et al. (2005) compared milk from healthy quarters with that from unhealthy quarters and found out a higher protein concentration in the milk from the latter throughout the whole milking. Milk obtained from mastitic quarters or presenting high SCC values showed high plasmin concentration (Le Roux et al. 1995). However, milk fat rate tends to decrease in cases of IMI (Philpot 1984, Hortet \& Seegers 1998). The increase in protein, fat, and consequently total solid rates, probably reflects other factors that are not necessarily the presence/absence of IMI (such as the decreased production). For these rates, there was no interaction between breed and season. Both breeds presented similar tendencies as to these variables.

Decreased milk production per cow due to clinical and subclinical mastitis is usually recognized as the main pa- thway to economic losses (DeGraves \& Fetrow 1993). In the present study, milk production significantly decreased in the rainy season probably due to external factors such as changes in the animal diet. It is known that milk production decreases as the concentration of total solids in the product increases. This justifies the increased rates of protein, total solid and fat in the milk.

SCC is the indicator most frequently used for subclinical mastitis in dairy cattle (Olde Riekerink et al. 2007). Breed and season had no significant effects on SCC in the milk. No interaction effect was observed between season and breed. Also, it was observed that Holstein cows had a higher increase in SCC when an IMI case was present in comparrison with Jersey cows. There seems to be differences between Holstein and Jersey cows in some aspects of immune response, as observed in other studies (Bannerman et al. 2008b).

Lactose rate was the only milk composition parameter that decreased when comparing the two seasons. High SCC milk had low lactose content, as reported by other authors (Park et al. 2007). This finding is due to the leakage in the blood-milk barrier, as well as to the reduced biosynthetic ability of secretory cells (Wickstrom et al. 2009). In the present study, the season influenced the percentage of lactose in the milk. The same cows had higher lactose rates in the dry season than in the rainy season. Conversely, fat, protein and total solid rates in the milk increased in the rainy season. Lactose rate in the milk can itself act as an indicator of mammary gland health, being more sensitive to detect an SCC increase than other components (Park et al., 2007). Healthy quarters had higher lactose content over the whole milking (Nielsen et al. 2005).

The frequency of IMI cases was higher in the rainy season than in the dry season, although the season alone did not have significant contribution according to the logistic regression model applied. However, the effect of interaction between season and breed was significant, showing distinct tendencies between the breeds in both seasons considering the output variable (IMI). Jersey cows had a lower chance of developing IMI signs and symptoms than Holstein cows in the rainy season $(\mathrm{OR}=0.52)$. This finding suggests that each breed was differently influenced by the season in the present study. Although innate immune responses are very similar in both breeds, there are differences in the temporal onset, cessation and duration of several immune parameters (Bannerman et al. 2008b). Bannerman et al. (2008a) compared the immune response of Jersey and Holstein cows subjected to controlled E. coli IMI. Although differences were observed, the innate immune response of Holstein and Jersey cows to E. coli IMI remained highly conserved.

In the present study, the higher frequency of IMI cases in the rainy season may have led to a lower lactose rate in the milk of both breeds. The lactose rate in the milk was expected to follow the same tendency of the other main components evaluated, but this did not occur. The larger number of IMI cases in the rainy season, although not showing a significant contribution to the model itself, may have lead to a decrease in the lactose rate in the milk and 
probably counteracted the tendency towards increased lactose rate when the product concentration was higher. The lactose rate in the milk can be considered an important indicator of mastitis and is more sensitive to changes than other milk components. In previous studies, the percentage of lactose in the milk was responsible for the identification of $76 \%$ mastitic cows; this data is higher than those obtained using other milk components (Bansal et al. 2005). Unlike protein and fat rate, the lactose rate in milk samples with low SCC values $\left(<200 \times 10^{3}\right.$ cells $\left./ \mathrm{mL}\right)$ was different from that in milk samples with slightly higher SCC (201-350 x10 $0^{3}$ cells $/ \mathrm{mL}$ ) (Park et al. 2007). The mean SCC values obtained in the present study were low $\left(<320 \times 10^{3}\right.$ cells $/ \mathrm{mL}$ ), which justifies the change in the milk component that is most sensitive to mastitis diagnosis: lactose. In previous studies, IMI was not associated with a decrease in the production of milk or its solids (Compton et al. 2007). Apparently, milk lactose rate could be sensitive to detect an IMI onset in a low count herd, proving to be an important component to be monitored in cows. However, we expected a significant interaction effect between breed and season when comparing the lactose rate of the two breeds, as it was observed a higher number of IMI cases in Holstein breeds in the rainy season. Although we cannot prove the relationship between lactose rate and IMI by our study (mainly because different diets were applied in the two seasons), we recommend more studies involving milk lactose rate in order to understand the true relationship between this component and mastitis.

There was a higher prevalence of contagious pathogens (especially Staphylococcus spp.). Several contagious mastitis pathogens are endemic to most countries with an undeveloped dairy industry. Eradication of contagious pathogens is still a challenge in Brazil. Even if a herd is already infected by contagious bacteria like Staphylococcus aureus, it is still required to prevent the introduction of animals infected by other contagious species, mainly because purchased animals may introduce a new pathogen strain (Barkema et al. 2009). Contagious pathogens like CNS have been extensively studied (De Vliegher et al. 2009, Sampimon et al. 2009, Onni et al. 2010) and their importance is reinforced in the present study due to the higher number of IMI cases. Conversely, both breeds were not influenced by the season regarding the type of pathogen isolated, although the number of IMI cases was larger in Holstein cows in the rainy season. The increased number of IMI cases by environmental pathogens is frequently associated with high rainfall (Schreiner \& Ruegg 2002), which was not observed in the present study. The applied model showed that environmental pathogens were more frequently isolated from the breed Jersey, regardless of the study season. Although this was not an original objective of the research, we attribute this finding due to the fact that the average lactation number of Jersey cows was significantly higher than the one observed in Holstein cows, which may contribute with teat lesions and loss of functionality of the teat sphincter. As showed in Table 2, the increase in one lactation number increases the chance of the animal developing IMI (OR=2.31). Nevertheless, it wasn't observed any significant increase in environmental mastitis in rainy season on both breeds.

\section{CONCLUSIONS}

Jersey and Holstein cows had distinct performances according to the season considering some of the evaluated aspects, especially the IMI status. Fat, protein and total solids rates in the milk increased in the rainy season for both breeds, mainly influenced by a lower milk production and changes in the animal's diet.

SCC remained unchanged, but Holstein cows with IMI presented a higher increase in SCC when compared to Jersey cows, suggesting differences in the immune response. The larger number of IMI cases in the rainy season may have led to a lower milk lactose rate for both breeds, thus milk lactose rate can be considered an indicator of IMI status.

Contagious pathogens were the most isolated pathogens in both seasons for both breeds.

Holstein cows were less adapted to high rainfall conditions based on its higher frequency of IMI cases in this season (not necessarily caused by environmental pathogens); an important aspect that indicates the presence of subclinical mastitis.

\section{REFERENCES}

Auldist M.J., Coats S.J., Sutherland B.J., Hardham J.F., McDowell G.H. \& Rogers G.L. 1996. Effect of somatic cell count and stage of lactation on the quality and storage life of ultra high temperature milk. J. Dairy Res. 63:377-386.

Bannerman D.D., Kauf A.C., Paape M.J., Springer H.R. \& Goff J.P. 2008a. Comparison of Holstein and Jersey innate immune responses to Escherichia coli intramammary infection. J. Dairy Sci. 91:2225-2235.

Bannerman D.D., Springer H.R., Paape M.J., Kauf A.C. \& Goff J.P. 2008b. Evaluation of breed-dependent differences in the innate immune responses of Holstein and Jersey cows to Staphylococcus aureus intramammary infection. J. Dairy Res. 75:291-301.

Bansal B.K., Hamann J., Grabowskit N.T. \& Singh K.B. 2005. Variation in the composition of selected milk fraction samples from healthy and mastitic quarters, and its significance for mastitis diagnosis. J. Dairy Res. 72:144152.

Barkema H.W., Green M.J., Bradley A.J. \& Zadoks R.N. 2009. Invited review: The role of contagious disease in udder health. J. Dairy Sci. 92:47174729.

Caraviello D.Z., Weigel K.A., Shook G.E. \& Ruegg P.L. 2005. Assessment of the impact of somatic cell count on functional longevity in Holstein and Jersey cattle using survival analysis methodology. J. Dairy Sci. 88:804811.

Compton C.W., Heuer C., Parker K. \& McDougall S. 2007. Epidemiology of mastitis in pasture-grazed peripartum dairy heifers and its effects on productivity. J. Dairy Sci. 90:4157-4170.

De Vliegher S., Zadoks R.N. \& Barkema H.W. 2009. Heifer and CNS mastitis. Vet Microbiol. 134:1-2.

DeGraves F.J. \& Fetrow J. 1993. Economics of mastitis and mastitis control. Vet. Clin. North Am., Food Anim. Pract. 9:421-434.

Field A. \& Miles J., 2010. Discovering Statistics using SAS. In: Wright D.B. (Ed.), Sage Publications Ltd, City, p.760.

Heins B.J., Hansen L.B., Seykora A.J., Hazel A.R., Johnson D.G. \& Linn J.G. 2008. Crossbreds of Jersey x Holstein compared with pure Holsteins for body weight, body condition score, dry matter intake, and feed efficiency during the first one hundred fifty days of first lactation. J Dairy Sci. 91:3716-3722. 
Hortet P. \& Seegers H. 1998. Calculated milk production losses associated with elevated somatic cell counts in dairy cows: review and critical discussion. Vet Res. 29:497-510.

Kelm S.C., Freeman A.E. \& Kehrli Jr M.E. 2001. Genetic control of disease resistance and immunoresponsiveness. Vet. Clin. North Am. Food Anim. Pract. 17:477-493.

Langoni H. 2000. [Modernization trends in the industry: milk quality monitoring by somatic cell counts]. Revta Educ. Contin. 3:57-64.

Le Roux Y., Colin O. \& Laurent F. 1995. Proteolysis in samples of quarter milk with varying somatic cell counts. 1 . Comparison of some indicators of endogenous proteolysis in milk. J. Dairy Sci. 78:12891297.

Le Roux Y., Laurent F. \& Moussaoui F. 2003. Polymorphonuclear proteolytic activity and milk composition change. Vet. Res. 34:629-645.

Morse D., DeLorenzo M.A., Wilcox C.J., Collier R.J., Natzke R.P. \& Bray D.R. 1988. Climatic effects on occurrence of clinical mastitis. J. Dairy Sci. 71:848-853.

Munoz M.A., Bennett G.J., Ahlstrom C., Griffiths H.M., Schukken Y.H. \& Zadoks R.N. 2008. Cleanliness scores as indicator of Klebsiella exposure in dairy cows. J. Dairy Sci. 91:3908-3916.

Nielsen N.I., Larsen T., Bjerring M. \& Ingvartsen K.L. 2005. Quarter health, milking interval, and sampling time during milking affect the concentration of milk constituents. J. Dairy Sci. 88:3186-3200.

National Mastitis Council, 1999. Laboratory Handbook on Bovine Mastitis. Natl Mastitis Counc. Inc., Madison, WI.

Ogola H., Shitandi A. \& Nanua J. 2007. Effect of mastitis on raw milk compositional quality. J.Vet. Sci. 8:237-242.

Olde Riekerink R.G., Barkema H.W., Veenstra W., Berg F.E., Stryhn H. \& Zadoks R.N. 2007. Somatic cell count during and between milkings. J. Dairy Sci. 90:3733-3741.
Onni T., Sanna G., Cubeddu G.P., Marogna G., Lollai S., Leori G. \& Tola S. 2010. Identification of coagulase-negative staphylococci isolated from ovine milk samples by PCR-RFLP of $16 \mathrm{~S}$ rRNA and gap genes. Vet. Microbiol. 144:347-352.

Park Y.K., Koo H.C., Kim S.H., Hwang S.Y., Jung W.K., Kim J.M., Shin S., Kim R.T. \& Park Y.H. 2007. The analysis of milk components and pathogenic bacteria isolated from bovine raw milk in Korea. J. Dairy Sci. 90:54055414.

Philpot W.N. 1984. Economics of mastitis control. Vet. Clin. North Am., Large Anim. Pract. 6:233-245.

Pyorala S. 2008. Mastitis in post-partum dairy cows. Reprod Domest Anim. 43 Suppl 2:252-259.

Sampimon O.C., Barkema H.W., Berends I.M., Sol J. \& Lam T.J. 2009. Prevalence and herd-level risk factors for intramammary infection with coagulase-negative staphylococci in Dutch dairy herds. Vet. Microbiol. 134:37-44.

Schalm O.W. \& Noorlander D.O. 1957. Experiments and observations leading to development of the California mastitis test. J. Am. Vet. Med. Assoc. 130:199-204.

Schreiner D.A. \& Ruegg P.L. 2002. Effects of tail docking on milk quality and cow cleanliness. J. Dairy Sci. 85:2503-2511.

Schreiner D.A. \& Ruegg P.L. 2003. Relationship between udder and leg hygiene scores and subclinical mastitis. J. Dairy Sci. 86:3460-3465.

Seegers H., Fourichon C. \& Beaudeau F. 2003. Production effects related to mastitis and mastitis economics in dairy cattle herds. Vet. Res. 34:475491.

Wickstrom E., Persson-Waller K., Lindmark-Mansson H., Ostensson K. \& Sternesjo A. 2009. Relationship between somatic cell count, polymorphonuclear leucocyte count and quality parameters in bovine bulk tank milk. J. Dairy Res. 76:195-201. 